\title{
Determination of fundamental criteria in the selection of a construction system
}

\author{
Mukhammet Fakhratov ${ }^{1}$, Sergey Sinenko ${ }^{1}$, Mohammad Akbari ${ }^{1 *}$, and Farid Asayesh ${ }^{1}$ \\ ${ }^{1}$ Moscow State University of Civil Engineering (National Research University), 26, Yaroslavskoye \\ Shosse, Moscow, Russia
}

\begin{abstract}
There is a lack of an efficient systematic approach to the selection of appropriate construction methods for modern building systems. Identifying key criteria is necessary to help decision-makers in implementing the principles of this process. The present article was conduct for the same purpose. In this article, after reviewing of the literature, we found that construction experts' opinions did not consider until now. Thus, we considered the opinion of experts in the field of the construction industry (Technical and executive specialists of the Afghanistan's Ministry of Urban Development and Housing, Technical and executive specialists of the Kabul Municipality and Omran Houlding Group). For identifying key criteria, "64" criteria have been extracted that affect the selection of modern building systems and are classified into "six" economic, qualitative, social, environmental, executive and technical groups. A comprehensive study conducted through the distribution of questionnaires. The collected data were analysed using SPSS statistical software; the main criteria ranked by using "Friedman's statistical test". Based on the results of statistical tests, 18 criteria were determined and ranked as fundamental criteria. Therefore, paying attention to these criteria for the selection of appropriate construction methods for modern building systems can help experts in the country of Afghanistan.
\end{abstract}

\section{Introduction}

The new methods of the building is a relatively new term that used to reflect the technical advances in housing forecasting. Kamali et al. [1] and Ren et al. [2] found that different construction methods influence project performance in various ways and impact on the productivity of construction projects; deficient methods decrease the productivity of projects. Furthermore, Forbes and Ahmed [3] posited that the choice of construction method significantly affects the cost, time, and quality of buildings, and adopting inappropriate methods increases the cost and duration of projects, as well as decreasing the quality and lifespan of buildings. Currently, the construction industry has been revolutionize and is experiencing changes, with the rapid growth of technology and the introduction of new building materials and modern construction methods, Harris and McCaffer [4]. Furthermore, the new generation of building regulations enacted to increase

\footnotetext{
${ }^{*}$ Corresponding author: sharif.farahmand@gmail.com
} 
the efficiency and improve the quality of buildings and infrastructure, Youssef et al. [5]. As a result, construction managers, as decision-makers, have to choose appropriate construction methods from those available. Therefore, to achieve construction project performance, there is a need for adequate information and knowledge to help construction managers to make good choices of construction methods.

In this article, we found, that construction experts' opinions did not consider currently. Thus we considered the opinion of "Technical and executive specialists of the Afghanistan's Ministry of Urban Development and Housing", "Technical and executive specialists of the Kabul Municipality" and "Omran Houlding Group" experts in the field of the construction industry, which the organizational profile of the experts is listed on the website of those organizations. For identifying key criteria, "64" criteria have been extracted that affect the selection of modern building systems and are classified into "six" economic, qualitative, social, environmental, executive and technical groups. A comprehensive study conducted through the distribution of questionnaires.

The focus of the article is on the determination of fundamental criteria because the selection of appropriate construction methods for modern building systems can help experts in Afghanistan country.

\section{Relevant works}

Choosing the most appropriate method is to construct a decisive factor in achieving optimal results and high productivity. Despite this, in many cases, this activity done without the necessary consideration and inadequate study of the available options, Fakhri et al [6]. This situation can have consequences such as lack of performance in the use of resources, inappropriate use of technologies, lack of attention to the most effective option for the work and absence of reuse of previous project experience, Youssef et al [7]. Also, the selection method is a multi-criteria decision-making process, Golabchi et al [8] and it is necessary to consider decision-makers of different factors in the relevant project (such as environmental features, access to force, etc.), our goals (reduce costs, more safety, etc.) Specify and finally choose a suitable method, Lovell [9]. This requires the use of a process in which experts and project team members apply their experience to choose the most effective way [10]. "Ferrada" \& "Serpell" [11] examined the different decision criteria used in the literature during the design and construction process of a project to select the most appropriate construction method. These criteria include time, cost, quality, risk, resource availability, production rate, environment, site features, security, method of construction, maintenance, etc. Chen et al [12] identified four sustainable performance measures based on the requirements of various project stakeholders. The results of this study show that social awareness and environmental concerns are very important in choosing the construction method. Also, based on the results of factor analysis of these criteria to seven dimensions, namely, economic factors: The long-term cost, manufacturing capability, in the research "Pan et. Al" [13], More than 50 criteria decision to select the construction systems developed to be the groups of cost, time, quality, health and safety, sustainability, process, procurement, and legal acceptance and regulation and classified according to the results. In order to cost, time and quality were dominant in the selection process on other criteria. In order to obtain a comprehensive view of the criteria affecting the selection of new methods of construction projects, in the present study, comprehensive research conducted on the criteria presented in related research. In table, 1, 64 the identified criteria reported along with their sources. These criteria determined by a study of relevant research, along with inputs, revisions, and changes made by experts of Afghanistan's construction industry, and based on the opinions of experts in the country's manufacturing industry in six groups of economists, qualitative, social, environmental, executive and technical and logistics. 
Table 1. Evaluation criteria for new building systems.

\begin{tabular}{|c|c|c|c|}
\hline Criteria & No. & Sub-criteria & Source \\
\hline \multirow{14}{*}{ Economical } & 1 & Initial system construction Cost & Tam et al. (2007) [14] \\
\hline & 2 & Design costs & Song et al. (2005) [15] \\
\hline & 3 & Cost of the life cycle & Soetanto et al. (2004) [16] \\
\hline & 4 & Maintenance costs & Nelms et al. (2007) [17] \\
\hline & 5 & Structure value & Chen et al. (2010) [18] \\
\hline & 6 & Return on investment speed & $\begin{array}{c}\text { Chen et al. (2010) [19] Abd } \\
\text { Hamid and Mohamad } \\
\text { Kamar (2011) [20] }\end{array}$ \\
\hline & 7 & Cost of materials and materials & Blismas and Wakefield \\
\hline & 8 & Labor costs & $(2007)[20]$ \\
\hline & 9 & $\begin{array}{l}\text { Impact on the cost of interface } \\
\text { systems (ceilings, walls, etc.) }\end{array}$ & Blismas and Wakefield \\
\hline & 10 & $\begin{array}{l}\text { Impact on the costs of related } \\
\text { items (required changes to the site, } \\
\text { scaffolding, elevator, etc.) }\end{array}$ & (2007) [20] \\
\hline & 11 & Cost-certainty & Pan et al (2012) [13] \\
\hline & 12 & Construction time & Balali et al. (2014) [13] \\
\hline & 13 & Delivery times & Pan et al (2012) [13] \\
\hline & 14 & Uncertainty of time & Pan et al (2012) [13] \\
\hline \multirow{11}{*}{ Qualitative } & 15 & $\begin{array}{c}\text { Compliance with construction } \\
\text { regulations }\end{array}$ & Pan et al(2012) [13] \\
\hline & 16 & $\begin{array}{l}\text { Building Control in the } \\
\text { construction process }\end{array}$ & Pan et al (2012) [13] \\
\hline & 17 & Defects (in delivery) & $\begin{array}{l}\text { Chen et al. (2010) [10] Pan } \\
\text { et al (2012) [13] }\end{array}$ \\
\hline & 18 & $\begin{array}{l}\text { Satisfaction and hire customers to } \\
\text { design }\end{array}$ & Pan et al (2012) [13] \\
\hline & 19 & flexibility (adaptability) & Pan et al (2012) [13] \\
\hline & 20 & Structural resistance & $\begin{array}{c}\text { Ferrada and Serpell (2014) } \\
{[11]}\end{array}$ \\
\hline & 21 & Seismic resistance & $\begin{array}{c}\text { Ferrada and Serpell (2014) } \\
{[11]}\end{array}$ \\
\hline & 22 & Resistance against fire & Balali et al (2014) [21] \\
\hline & 23 & $\begin{array}{l}\text { The possibility of retrofitting in } \\
\text { the future }\end{array}$ & Balali et al (2014) [21] \\
\hline & 24 & Performance of building lifecycle & Pan et al (2012) [13] \\
\hline & 25 & Durability & Chen et al. (2010) [10] \\
\hline \multirow{5}{*}{ Social } & 26 & $\begin{array}{c}\text { Safety and Health Concerns for } \\
\text { Workers }\end{array}$ & $\begin{array}{l}\text { Chen et al. (2010) [10] } \\
\text { Chen et al. (2010) [18] }\end{array}$ \\
\hline & 27 & $\begin{array}{c}\text { Residents' health (indoor air } \\
\text { quality) }\end{array}$ & Pan et al(2012) [13] \\
\hline & 28 & Impact on the labor market & Chen et al. (2010) [10] \\
\hline & 29 & Physical space & Chen et al. (2010) [10] \\
\hline & 30 & Beauty Options & Chen et al. (2010) [10] \\
\hline \multirow[t]{2}{*}{ Environmental } & 31 & $\begin{array}{l}\text { Energy consumption in design and } \\
\text { construction }\end{array}$ & $\begin{array}{l}\text { Chen et al. (2010) [10] } \\
\text { Tam et al. (2007) [14] }\end{array}$ \\
\hline & 32 & Consumption of materials & Chen et al. (2010) [16] \\
\hline
\end{tabular}




\begin{tabular}{|c|c|c|c|}
\hline Criteria & No. & Sub-criteria & Source \\
\hline & 33 & Waste production & $\begin{array}{c}\text { Chen et al. (2010) [10] Pan } \\
\text { et al (2012) [13] }\end{array}$ \\
\hline & 34 & Production of pollution & $\begin{array}{l}\text { Chen et al. (2010) [10] } \\
\text { Chen et al. (2010) [18] }\end{array}$ \\
\hline & 35 & $\begin{array}{l}\text { Energy efficiency when using the } \\
\text { building }\end{array}$ & $\begin{array}{l}\text { Chen et al. (2010) [10] } \\
\text { Chen et al. (2010) [18] }\end{array}$ \\
\hline & 36 & Recyclability in the industry & $\begin{array}{c}\text { Jaillon and Poon (2008) } \\
{[22]}\end{array}$ \\
\hline & 37 & $\begin{array}{l}\text { Adaptation to climatic and } \\
\text { environmental conditions }\end{array}$ & $\begin{array}{l}\text { Chen et al. (2010) [10] } \\
\text { Chen et al. (2010) [18] } \\
\end{array}$ \\
\hline \multirow{8}{*}{$\begin{array}{l}\text { Executive and } \\
\text { Technical }\end{array}$} & 38 & $\begin{array}{l}\text { Design repeatability and } \\
\text { standardization }\end{array}$ & $\begin{array}{c}\text { Gibb and Isack (2001)[23] } \\
\text { Song et al. (2005) [15] } \\
\text { Pan et al (2012) [13] } \\
\text { Chen et al. (2010) [18] }\end{array}$ \\
\hline & 39 & Executable (build) & Chen et al. (2010) [10] \\
\hline & 40 & Ease of implementation & Balali et al (2014) [21] \\
\hline & 41 & Design flexibility & Gibb and Isack (2001) [23] \\
\hline & 42 & Use in future projects & Pan et al (2012) [13] \\
\hline & 43 & Height limitation & Pan et al (2012) [13] \\
\hline & 44 & Structural Weight & $\begin{array}{c}\text { Ferrada and Serpell (2014) } \\
\text { [11] }\end{array}$ \\
\hline & 45 & production capacity & Pan et al(2012) [16] \\
\hline \multirow{17}{*}{$\begin{array}{l}\text { Procurement / } \\
\text { logistics }\end{array}$} & 46 & $\begin{array}{l}\text { Supply chain (transfer from the } \\
\text { factory to site and inside the site, } \\
\text { warehouse, etc.) }\end{array}$ & $\begin{array}{c}\text { Chen et al. (2010) [10] Abd } \\
\text { Hamid and }\end{array}$ \\
\hline & 47 & $\begin{array}{c}\text { Ease of site coordination (e.g., } \\
\text { mechanic and Electric) }\end{array}$ & $\begin{array}{c}\text { Hamid \& Kamar (2011) } \\
{[24]}\end{array}$ \\
\hline & 48 & Planning and honesty to site & Pan et al (2012) [13] \\
\hline & 49 & Building Services Integration & Pan et al (2012) [13] \\
\hline & 50 & $\begin{array}{l}\text { The availability of local } \\
\text { localization companies }\end{array}$ & Pan et al (2012) [13] \\
\hline & 51 & Qualified workers & Chen et al. (2010) [10] \\
\hline & 52 & $\begin{array}{l}\text { Availability of equipment for } \\
\text { installation and commissioning }\end{array}$ & Chen et al. (2010) [18] \\
\hline & 53 & Required Force & $\begin{array}{c}\text { Ferrada and Serpell (2014) } \\
{[11]}\end{array}$ \\
\hline & 54 & System Market Availability & Pan et al (2012) [13] \\
\hline & 55 & Previous manufacturer Experience & Pan et al (2012) [13] \\
\hline & 56 & $\begin{array}{c}\text { Manufacturer/vendor competence } \\
\text { and capability }\end{array}$ & Pan et al (2012) [13] \\
\hline & 57 & $\begin{array}{l}\text { Contractual risk } \\
\end{array}$ & Pan et al (2012) [13] \\
\hline & 58 & Depending on specific machines & Balali et al (2014) [21] \\
\hline & 59 & $\begin{array}{c}\text { The space required to build } \\
\text { structures }\end{array}$ & Youssef et al (2005) [5] \\
\hline & 60 & $\begin{array}{l}\text { Execution expertise, and the need } \\
\text { for expert workforce }\end{array}$ & Soetanto \\
\hline & 61 & Country record & et al. (2007) [18] \\
\hline & 62 & $\begin{array}{c}\text { Fit into the architecture of the } \\
\text { country }\end{array}$ & \\
\hline
\end{tabular}




\begin{tabular}{|c|c|c|c|}
\hline Criteria & No. & Sub-criteria & Source \\
\hline & 63 & $\begin{array}{c}\text { Seasonal and seasonal restrictions } \\
\text { on system use }\end{array}$ & Pan et al (2012) [13] \\
\cline { 2 - 4 } & 64 & $\begin{array}{c}\text { Permission and Restriction of } \\
\text { Transportation and Pre-Elements } \\
\text { (Delivery Logistics) }\end{array}$ & Pan et al (2012) [13] \\
\hline
\end{tabular}

\section{Research method}

The present study was conduct in descriptive-survey research. The required data is collected through a literature review related to the subject and field studies. The statistical population of the present study is experts and decision-makers, including consultants and contractors of contractor companies and active consultant engineering in the field of building industry located in Kabul City. According to the wider population, the size of the appropriate statistical sample for this study based on Cochran's sampling formula, which was 96 to determine the sample size in unlimited communities. The required data obtained from distributed questionnaires among the samples. To determine the criteria for critical selection in the evaluation of new construction systems from among 64 identified criteria and their ranking, a questionnaire with a range of five "Likert options" developed and the experts asked to determine the importance of each criterion by choosing the appropriate option. Both experts of all ranges of experience confirmed the questionnaire's validity. The Cronbach's alpha confirmed by the questionnaire to assess its reliability using SPSS software $(0.903)$ and since it was more than $(0.7)$. The collected data analyzed through questionnaires using descriptive and inferential statistic tools. In order to determine the criteria of critical selection from the initial criteria, the parametric T-student and "Wilcoxon non-parametric tests" used in SPSS software at a 5\% error level. "Friedman statistical test" used to evaluate the final ranking criteria.

\section{Research findings}

Descriptive analysis of demographic characteristics of respondents showed that more than $50 \%$ of them have work experience more than 10 years in the construction of new construction systems and more than $60 \%$ of respondents have postgraduate and doctoral education. In the inferential analysis, the statistical hypothesis associated with each criterion of the questionnaire defined in the same way: "These criteria for selecting the most appropriate method of buildings in the country are very important, and it is considered as fundamental criteria". Considering that in the questionnaire with experts and professors, the scale of five "Likert" options used, the Test Value for measuring assumptions equals four considered. First, the data need to be test for normality or non-normality. For this purpose, the "Kolmogorov-Smirnov test" (K-S) is used. Then, the t-student parametric test used to test the hypotheses if the hypothesis not rejected; otherwise, the Wilcoxon nonparametric test is used. The Null hypothesis of these tests defined as the mean (for the parametric test) or the median (for the nonparametric test) is bigger or equal than "4". If the value of the "P test" is more than the intended error level (0.05), then criteria accepted as a fundamental and effective criterion in selecting the most appropriate method of building in the country. The results of the normal data analysis using the "K-S" test showed that, except three criteria for maintenance costs, physical space and ease of site coordination, other criteria did not follow the normal distribution (P-value $<=0.05)$ and it is necessary to check their critical use of nonparametric tests. In order to summarize the paper, the test results "KS" have not reported. In Tables 2 and 3, the results of the "Wilcoxon" single-sample test 
and one-sample "T-Test" were reported. Critical selection criteria highlighted in these tables. As we can see, 18 criteria selected as critical criteria for assessing and selecting new construction systems with experts and experts in the country.

Table 2. One-sample "T-test" results for data with normal distribution.

\begin{tabular}{|c|c|c|c|c|c|c|}
\hline Criteria & No. & Sub-Criteria & Mean & SD & T-Value & $\begin{array}{c}\text { P- } \\
\text { Value }\end{array}$ \\
\hline Economic & 4 & Maintenance costs & 2.99 & 1.395 & -7.09 & 0 \\
\hline Social & 29 & Physical space & 2.979 & 1.407 & -7.08 & 0 \\
\hline $\begin{array}{c}\text { Procurement / } \\
\text { Logistic }\end{array}$ & 47 & $\begin{array}{c}\text { Ease of site } \\
\text { coordination }\end{array}$ & 3.01 & 1.41 & -6.87 & 0 \\
\hline
\end{tabular}

Table 3. One-sample "Wilcoxon test" results for non-normal data.

\begin{tabular}{|c|c|c|c|c|c|}
\hline Criteria & No. & Sub-Criteria & $\begin{array}{l}\text { Wilcoxon } \\
\text { statistic }\end{array}$ & P-Value & $\begin{array}{c}\text { Estimated } \\
\text { Median }\end{array}$ \\
\hline \multirow{13}{*}{ Economical } & 1 & $\begin{array}{c}\text { Initial system } \\
\text { construction Cost }\end{array}$ & 1400 & 0.002 & 3.5 \\
\hline & 2 & Design costs & 1120 & 0.018 & 4 \\
\hline & 3 & Cost of life cycle & 184.5 & 0 & 3 \\
\hline & 5 & Structure value & 336 & 0 & 3 \\
\hline & 6 & $\begin{array}{l}\text { Return on investment } \\
\text { speed }\end{array}$ & 936 & 0 & 3 \\
\hline & 7 & Cost of materials & 3465 & 1 & 5 \\
\hline & 8 & Labor costs & 1764 & 0.989 & 4.5 \\
\hline & 9 & $\begin{array}{l}\text { Impact on the cost of } \\
\text { interface systems } \\
\text { (ceilings, walls, etc.) }\end{array}$ & 480 & 0 & 3 \\
\hline & 10 & $\begin{array}{l}\text { Impact on the costs of } \\
\text { related items (required } \\
\text { changes to the site, } \\
\text { scaffolding, elevator, } \\
\text { etc.) }\end{array}$ & 1313.5 & 0.002 & 3.5 \\
\hline & 11 & Cost-certainty & 575 & 0 & 3.5 \\
\hline & 12 & Construction time & 2520 & 1 & 4.5 \\
\hline & 13 & Delivery times & 344 & 0 & 3 \\
\hline & 14 & Uncertainty of time & 480 & 0 & 3 \\
\hline \multirow{9}{*}{ Quantitative } & 15 & $\begin{array}{c}\text { Compliance with } \\
\text { construction } \\
\text { regulations }\end{array}$ & 2537 & 0.961 & 4 \\
\hline & 16 & $\begin{array}{l}\text { Building Control in the } \\
\text { construction process }\end{array}$ & 147 & 0 & 3 \\
\hline & 17 & Defects (in delivery) & 1188 & 0.006 & 4 \\
\hline & 18 & $\begin{array}{l}\text { Satisfaction and hire } \\
\text { customers design }\end{array}$ & 841 & 0.021 & 4 \\
\hline & 19 & $\begin{array}{l}\text { flexibility (adaptability } \\
\text { and adaptability) }\end{array}$ & 1037 & 0.043 & 4 \\
\hline & 20 & Structural resistance & 2814 & 0.996 & 4.5 \\
\hline & 21 & Seismic resistance & 3394.5 & 1 & 5 \\
\hline & 22 & Resistance against fire & 1419 & 0.978 & 4 \\
\hline & 23 & The possibility of & 966 & 0 & 3.5 \\
\hline
\end{tabular}




\begin{tabular}{|c|c|c|c|c|c|}
\hline Criteria & No. & Sub-Criteria & $\begin{array}{l}\text { Wilcoxon } \\
\text { statistic }\end{array}$ & P-Value & $\begin{array}{c}\text { Estimated } \\
\text { Median }\end{array}$ \\
\hline & & $\begin{array}{l}\text { retrofitting in the } \\
\text { future }\end{array}$ & & & \\
\hline & 24 & $\begin{array}{c}\text { Performance of } \\
\text { building lifecycle }\end{array}$ & 144 & 0 & 3.5 \\
\hline & 25 & Durability & 2848 & 0.999 & 4.5 \\
\hline \multirow{4}{*}{ Social } & 26 & $\begin{array}{l}\text { Safety and Health } \\
\text { Concerns for Workers }\end{array}$ & 1171.5 & 0.007 & 4 \\
\hline & 27 & $\begin{array}{l}\text { Residents' health } \\
\text { (indoor air quality) }\end{array}$ & 1650 & 0.014 & 4 \\
\hline & 28 & $\begin{array}{l}\text { Impact on the labor } \\
\text { market }\end{array}$ & 51 & 0 & 3 \\
\hline & 30 & Beauty Options & 211.5 & 0 & 3.5 \\
\hline \multirow{7}{*}{ Environmental } & 31 & $\begin{array}{l}\text { Energy consumption in } \\
\text { design and } \\
\text { construction }\end{array}$ & 2251.5 & 0.969 & 4 \\
\hline & 32 & $\begin{array}{c}\begin{array}{c}\text { Consumption of } \\
\text { materials }\end{array} \\
\end{array}$ & 782 & 0 & 3 \\
\hline & 33 & Waste production & 1548 & 0.807 & 4 \\
\hline & 34 & Production of pollution & 1924 & 0.928 & 4 \\
\hline & 35 & $\begin{array}{l}\text { Energy efficiency } \\
\text { when using the } \\
\text { building }\end{array}$ & 1138.5 & 0 & 3.5 \\
\hline & 36 & $\begin{array}{l}\text { Recyclability in the } \\
\text { industry }\end{array}$ & 1120 & 0 & 3.5 \\
\hline & 37 & $\begin{array}{l}\text { Adaptation to climatic } \\
\text { and environmental } \\
\text { conditions }\end{array}$ & 1512 & 0.032 & 4 \\
\hline \multirow{8}{*}{$\begin{array}{l}\text { Executive and } \\
\text { Technical }\end{array}$} & 38 & $\begin{array}{l}\text { Design repeatability } \\
\text { and standardization }\end{array}$ & 900 & 0 & 3 \\
\hline & 39 & Executable (build) & 2937 & 0.999 & 4.5 \\
\hline & 40 & $\begin{array}{c}\text { Ease of } \\
\text { implementation }\end{array}$ & 3036 & 1 & 4.5 \\
\hline & 41 & Design flexibility & 1206 & 0 & 3.5 \\
\hline & 42 & Use in future projects & 476 & 0 & 3.5 \\
\hline & 43 & Height limitation & 660 & 0.988 & 4 \\
\hline & 44 & Structural Weight & 1435 & 0.914 & 4 \\
\hline & 45 & production capacity & 1120 & 0.027 & 4 \\
\hline \multirow{4}{*}{$\begin{array}{l}\text { Procurement / } \\
\text { Logistic }\end{array}$} & 46 & $\begin{array}{l}\text { Supply chain (transfer } \\
\text { from the factory to site } \\
\text { and inside the site, } \\
\text { warehouse, etc.) }\end{array}$ & 1040 & 0.031 & 4 \\
\hline & 48 & $\begin{array}{l}\text { Planning and honesty } \\
\text { to site }\end{array}$ & 783 & 0.029 & 4 \\
\hline & 49 & $\begin{array}{c}\text { Building Services } \\
\text { Integration }\end{array}$ & 423 & 0 & 3 \\
\hline & 50 & $\begin{array}{l}\text { The availability of } \\
\text { local localization } \\
\text { companies }\end{array}$ & 2866.5 & 0.999 & 4.5 \\
\hline
\end{tabular}




\begin{tabular}{|c|c|c|c|c|c|}
\hline Criteria & No. & Sub-Criteria & $\begin{array}{c}\text { Wilcoxon } \\
\text { statistic }\end{array}$ & P-Value & $\begin{array}{c}\text { Estimated } \\
\text { Median }\end{array}$ \\
\hline & 51 & Qualified workers & 198 & 0 & 3 \\
\hline & 52 & $\begin{array}{l}\text { Availability of } \\
\text { equipment for } \\
\text { installation and } \\
\text { commissioning }\end{array}$ & 2610 & 0.999 & 4.5 \\
\hline & 53 & Required Force & 52.5 & 0 & 3 \\
\hline & 54 & $\begin{array}{c}\text { System Market } \\
\text { Availability }\end{array}$ & 1105 & 0.002 & 3.5 \\
\hline & 55 & $\begin{array}{l}\text { Previous manufacturer } \\
\text { Experience }\end{array}$ & 200 & 0 & 3.5 \\
\hline & 56 & $\begin{array}{l}\text { Manufacturer/vendor } \\
\text { competence and } \\
\text { capability }\end{array}$ & 1239.5 & 0.016 & 4 \\
\hline & 57 & Contractual risk & 575 & 0.004 & 3.5 \\
\hline & 58 & $\begin{array}{c}\text { Depending on specific } \\
\text { machines }\end{array}$ & 157.5 & 0 & 3 \\
\hline & 59 & $\begin{array}{c}\text { The space required to } \\
\text { build structures }\end{array}$ & 112.5 & 0 & 3 \\
\hline & 60 & $\begin{array}{c}\text { Execution expertise, } \\
\text { and the need for expert } \\
\text { workforce }\end{array}$ & 3412.5 & 1 & 5 \\
\hline & 61 & Country record & 423 & 0.002 & 3.5 \\
\hline & 62 & $\begin{array}{l}\text { Fit into the architecture } \\
\text { of the country }\end{array}$ & 1258 & 0.029 & 4 \\
\hline & 63 & $\begin{array}{l}\text { Seasonal and seasonal } \\
\text { restrictions on system } \\
\text { use }\end{array}$ & 627 & 0.003 & 3.5 \\
\hline & 64 & $\begin{array}{c}\text { Permission and } \\
\text { Restriction of } \\
\text { Transportation and } \\
\text { Pre-Elements } \\
\text { (Delivery Logistics) }\end{array}$ & 0 & 0 & 3.5 \\
\hline
\end{tabular}

Finally, in order to complete the study, 18 basic criteria affecting the selection of new construction systems compared with the "Friedman statistical test". The results of this test reported in tables " 4 " and "5". Since the significance level of the test statistic is less than (0.05), there is a significant difference between these criteria and therefore the ranking is significant. "Figure 1" shows the final ranking of fundamental criteria in selecting new methods of building projects.

Table 4. The "Friedman test" results for significant evaluation of criteria differences.

\begin{tabular}{|c|c|}
\hline Chi-Square & 85.877 \\
\hline Degrees of Freedom & 17 \\
\hline Significance (sig.) & 0.000 \\
\hline
\end{tabular}

Table 5. The Friedman test results for ranking criteria.

\begin{tabular}{|c|c|c|}
\hline Rating & $\begin{array}{c}\text { Friedman average } \\
\text { rating }\end{array}$ & Criteria \\
\hline 1 & 11.42 & Cost and material \\
\hline
\end{tabular}




\begin{tabular}{|c|c|c|}
\hline Rating & $\begin{array}{c}\text { Friedman average } \\
\text { rating }\end{array}$ & Criteria \\
\hline 13 & 8.84 & Labor cost \\
\hline 4 & 10.17 & Construction time \\
\hline 11 & 9.12 & Compliance with construction regulations \\
\hline 8 & 9.81 & Structural resistance \\
\hline 3 & 10.81 & Seismic resistance \\
\hline 15 & 8.39 & Resistance against fire \\
\hline 7 & 9.85 & Durability \\
\hline 12 & 9.07 & Waste production \\
\hline 17 & 8.11 & Pollution production \\
\hline 14 & 8.8 & Executive capability \\
\hline 5 & 10.01 & Ease of execution \\
\hline 6 & 9.91 & Height limit \\
\hline 18 & 8.01 & Structure weight \\
\hline 16 & 8.21 & The availability of local localization companies \\
\hline 9 & 9.79 & Availability of equipment for installation and \\
commissioning
\end{tabular}

The Friedman test results for ranking criteria reported in "Tables 5".

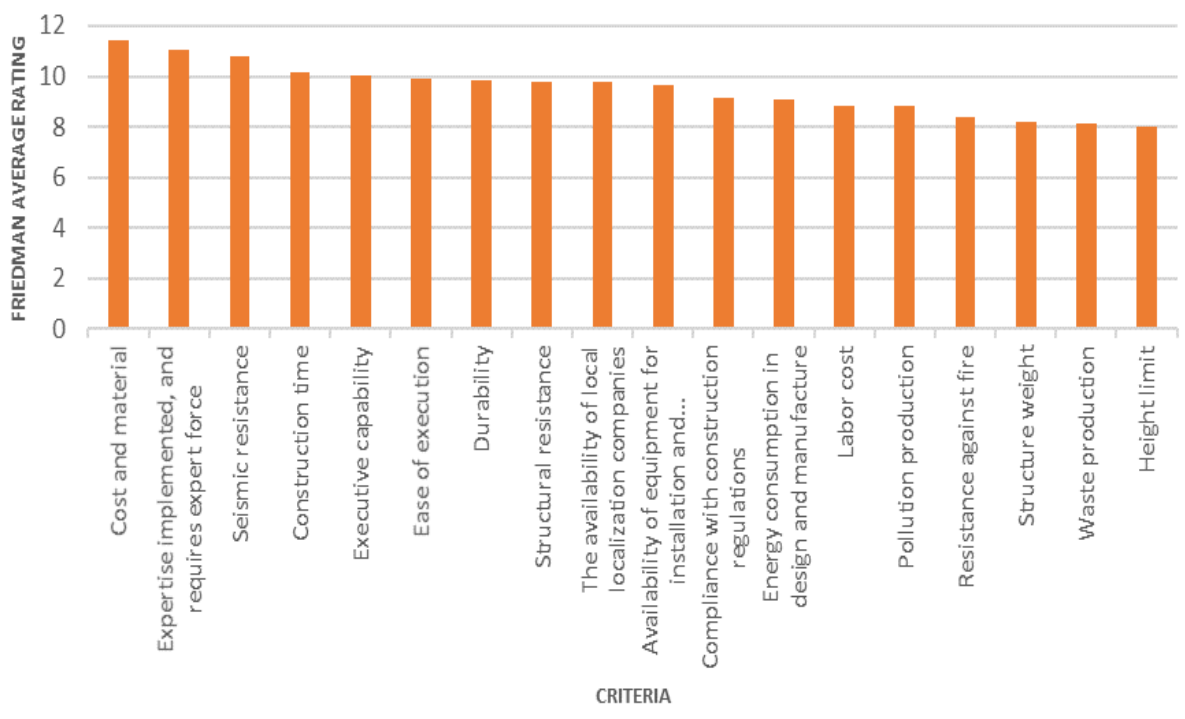

Fig. 1. The final ranking of fundamental criteria in the selection of new methods of construction projects.

The final ranking of fundamental criteria in selecting new methods of building projects shows in "Figure 1". 


\section{Conclusion}

In this study, the criteria of critical selection for the use of new construction systems in the country's manufacturing industry identified, evaluated and ranked. Based on the findings of the study, among 18 critical criteria identified, the cost of materials and materials, expertise in implementation, the need for human resources specialist and seismic resistance, according to the technical expert's opinion in the country's manufacturing industry, they have the first rank to the third rank. Therefore, paying attention to these criteria for the selection of appropriate construction methods for modern building systems can help experts in the country. Finally, it suggested that in future research, a more comprehensive study conducted to consider the views of other experts and experts in the country's manufacturing industry. Further studies suggest to be compare the new building systems with the help of multi-criteria decision-making techniques and considering the developed criteria in this study.

\section{References}

1. M. Kamali, K. Hewage, AS. Milani, Build. \& Envir. 138, 21-41 (2018)

2. Z. Ren, G. Shen, X. Xue, J. Manag. Eng. 29, 25-34 (2011)

3. L.H. Forbes, SM. Ahmed, Crc Press, (2010)

4. F. Harris, R. Caffer, John Wiley \& Sons, (2013)

5. T. Youssef, M. Anumba, Reston VA, (2005)

6. M. Fakhri, A. Beaming, J. Urban Plan. Arc. ,(2009)

7. T. Youssef, M. Anumba, C. Thorpe, ASCE, (2005)

8. M. Golabchi, H. Mazaherian, New const. Tech. Tehran Univ. Pr. , (2013)

9. H. Lovell, Modern Meth. Con., (2012)

10. C. Study, V. Balali, B. Zahraie, A. Roozbahani, App. Sel. Appro. Str. Sys. April , 297- 314 (2014)

11. X. Ferrada, A. Serpell, J. Constr. Eng. Manag. 140 ,(2014)

12. Y. Chen, G. E. Okudan, D. R. Riley, Autom. Constr 19, (2010)

13. W. Pan, A. R. J. Dainty, M. Asce, A.G.F. Gibb, (2012)

14. V. W. Y. Tam, C. M. Tam, S. X. Zeng W. C. Y. Ng, (2007)

15. J. Song, W. Fagerlund, C. Haas, C. Tatum, J. A. Vanegas, J. Constr. Eng. Manag. 131, 72333 (2005)

16. R. Soetanto, A. R. Dainty, J. Glass, A. D. F. Price, Eng. Constr. Archit. Manag. 11, 41424 (2004)

17. C. Nelms, A. Russell, B. J. Lence, Build. Res. Inf. 35, 237-51 (2007)

18. Y. Chen, G. E. Okudan, D. R. Riley, Autom. Constr. 19, 235-244 (2010)

19. K. A. M. Hamid, Z.A. Kamar, Constr. Innov. Information 12, 4 (2011)

20. R. Blismas, N. Wakefield, Constr. Innov. Spec. Ed., (2007)

21. A. Balali, V. Zahraie, B. Hosseini, A. Roozbahani, Eng. Syst. Manag., (2010)

22. C.S. Jaillon, L. Poon, Constr. Manag. Econ. 26, 953-66 (2008)

23. F. Gibb, A.G.F. Isack, Archit. Manag. 8, 46-58 (2001)

24. K.A.M. Hamid, Z.A. Kamar, Constr. Innov. Info. Pro. Manag. 12, 4 (2011) 